\title{
Ses Temelli Cümle Yöntemi ile İlk Okuma Yazma Öğretiminde Anlamlı Okumayı Etkileyen Unsurlar
}

\author{
The Factors Affecting Meaningful Reading through Phonetic Based Method
}

\section{Ayşe Nur KUTLUCA CANBULAT*}

Özet: Bu çalışmada Ses Temelli Cümle Yöntemi ile ilk okuma yazma öğretiminde anlamlı okumayı etkileyen unsurlar belirlenmeye çalışılmıştır. Araştırmada veriler nitel araştırmalarda kullanılan doküman incelemesi, gözlem ve görüşme yoluyla toplanmıştır. 2012-2013 öğretim yılında gerçekleştirilen araştırmanın doküman inceleme sürecinde Bolu ili ilköğretim okulları arasından basit şans yoluyla seçilmiş bir ilköğretim okulunda kullanılan Milli Eğitim Bakanlığı Talim Terbiye Kurulu tarafından beş yıl süre ile onaylanmış okuma-yazma öğretimi ders kitabı, yardımcı kaynak olarak bir okuma seti ve aynı okulun seçilen bir şubesinin sınıf öğretmeni tarafından hazırlanmış çalışma yaprakları incelenmiştir. İncelenen bu ders materyallerinin Türkçe’ye ses ve anlam açısından uygunluğu ile ilgili Türkçe uzmanlarının görüşüne başvurulmuş ve ilgili bulgular uzman görüşüne bağlı olarak sunulmuştur. Araştırmanın görüşme boyutunda ayrıca, aynı okulun seçilen birinci sınıf şubesi öğretmeni ve öğrencilerinin velileri ile görüşülmüş, araștırmanın gözlem boyutunda da okuma yazma öğretiminde sıkıntı yașayan 10 öğrencinin okuma süreci gözlenmiştir. Araştırma sonucunda öğrenci özellikleri, kullanılan yöntem, yöntemin uygulayıcısı olarak öğretmen ve öğretim uygulamaları ve hazırlanmış ders materyallerinin bir bütün olarak ve anlamlı okumayı etkilediği söylenebilir.

Anahtar sözcükler: İlk okuma yazma öğretimi, Ses Temelli Cümle Yöntemi, anlamlı okuma

\begin{abstract}
In this study the attempt was made to determine the factors that affect meaningful reading through the phonetic based method. Research data was collected through document analysis, interviews and observation. In this study conducted in the 2012-2013 academic year; the data collection tools for the document analysis were as follows: a text book offered by the Board of Education and Discipline (TTK), a workbook chosen and used by home-room teachers working at a state-run school and worksheets prepared by the teacher at the same school were examined. In the document analysis process, opinions of Turkish experts were taken concerning the examined course materials for the relevance of the sentences used in these teaching materials, which were analyzed. Interviews were conducted with parents of randomly selected first graders attending a state-run school in Bolu. After the interviews 10 students having difficulties in learning to read and write were observed. As a result of this research it can be said that the student characteristics, the methods used in literacy teaching, the teacher as a practitioner of method and his/her teaching applications and the prepared course materials influenced the meaningful reading process.
\end{abstract}

Keywords: Literacy teaching, Phonetic Based Method, meaningful reading

İnsan doğduğu andan itibaren çevresinde olup biteni okur ve anlamlandırmaya, bağlamını kavramaya çalışır. Ancak yazılı materyallerin okunup anlamlandırma süreci okuma yazma öğrenme

\footnotetext{
*Yrd. Doç. Dr., Akdeniz Üniversitesi, Eğitim Fakültesi, Sınıf Öğretmenliği ABD., aysenur.canbulat@gmail.com
} 
ile mümkündür ve formal okuma-yazma öğretim süreci ilköğretim birinci sınıfta başlar. Bu sınıf seviyesinde yapılan ilköğretim de literatürde ilk okuma yazma öğretimi şeklinde yer almaktadır. Bu yönüyle bu sürecinin bireyin öğrenim hayatı boyunca kullanacağı ve etkilerini taşıyacağı en önemli öğretim süreci olduğu söylenebilir.

İlk okuma-yazma öğretimi, dinleme, konuşma, okuma yazma olmak üzere dört temel dil becerisini geliştirmeye yönelik bir süreç olmakla birlikte genel olarak okuma yazma temel becerilerini kazandırmak için yapılan öğretim (Güleryüz, 1991) olarak da tanımlanabilmektedir.

İlk okuma yazma öğretiminin amacı bireye yaşam boyu kullanacağı temel dil becerilerini, okuduğunu anlama, kendini yazılı ve sözlü olarak ifade edebilme becerisini kazandırmak, anadiline karşı duyarlı bireyler yetiştirmektir. Çünkü okuma yazma öğretimi ile kazandırılacak beceri ve alışkanlıkların niteliği bireyin gelecekteki başarısını ya da başarısızlığını büyük oranda etkileyecektir. İlköğretim, ortaöğretim ve yükseköğretim kurumlarındaki başarısızlığın temelinde çoğu zaman okuma, anlama ve ifade yetersizlikleri yatmaktadır. Bu yetersizliklerin birçoğu da, ilk okuma ve yazma öğretimi sırasında iyi alışkanlıkların kazandırılamamış olmasına bağlanabilir (Öz, 1998). Bundan dolayı denilebilir ki, nasıl ilköğretim her şeyin temeli ise, ilk okuma yazma öğrenimi de ilköğretimin temeli (Kavcar, Oğuzkan, \& Sever 1997) ve bireyin okul başarısının belirleyicisidir. Bu yönüyle bu sürecin çok iyi yapılandırılması, dil becerilerinin çok yönlü gelişimine olanak sağlaması gerekir.

Bireyin kendi uğraş alanında ilerlemesi, önemli görevlere gelmesi ancak gelişmiş bir okuma-yazma becerisine sahip olmasıyla mümkündür. Çünkü çağdaş insan etkin bir okuma becerisine sahip olmadan istenilen düzeyde bir bilgi birikimine sahip olamaz. Bu nedenle ilk okuma yazma öğretiminde amaç, çocuğa sadece okuma-yazma becerisini kazandırmak değil, aynı zamanda çocuğun hızlı, doğru ve anlayarak okuması, okumaktan zevk alması ve elde ettiği bilgi birikimini çevresiyle paylaşabilmesi için işlevsel bir yazma yeteneği (Çelenk, 2007) geliştirmek olmalıdır. Bu bağlamda ilk okuma ve yazma öğretimi kelimeleri çözmek ve cümle kurmaktan öte, aynı zamanda fonksiyonel bir okur-yazarlık eğitimine hizmet etmelidir. Bu yönüyle amacı, okuduğunu ve dinlediğini anlayabilen; kendi duygu ve düşüncelerini etkili bir şekilde ifade edebilecek nitelikte bir okur-yazarlık becerisine sahip (Özden, 1999) bireyler yetiştirmek olmalıdır.

Türkiye'de tüm dünyada olduğu gibi okuma ve yazma öğretimi için geçmişten günümüze kadar birçok yöntem denenmiştir. Kullanılan yöntemlere genel anlamıyla bakıldığında bu yöntemlerin ses temelli yöntemler (alfabe yöntemi, ses yöntemi, hece yöntemi), okuduğunu anlamayı esas alan yöntemler (cümle yöntemi, kelime yöntemi, öykü yöntemi), karma yöntem (fonetik-hece, fonetik-kelime, kelime-hikâye-cümle) gibi yöntemler olduğu anlaşılmaktadır (Çelenk, 2002; Güneş, 2005; Akyol, \& Temur, 2008).

Türkiye’de öğretimde kullanılan son iki yöntem ele alındığında 1982’den 2005 yılına kadar ilk okuma yazmada Çözümleme Yöntemi ile okuma-yazma öğretimi yapılmıştır. İlk uygulanması 20. yüzyılın başlarında Belçika’da yapılmaya başlanmış daha sonra Avrupa ve Amerika'da uygulanmış (Binbaşıoğlu, 2005) olan Çözümleme Yöntemi’nin çıkış kaynağı Gestalt Psikolojisine dayanmaktadır ve buna göre de bütün, parçaların toplamından farklı ve özgün bir karaktere sahiptir. Bu nedenle de kalıcı ve etkin bir öğrenmenin sağlanması için öğrenenler için öğrenme yaşantıları anlamlı bir bütün halinde örgütlenmeli ve sunulmalıdır (Çelenk, 2007). Bu anlayışa dayanan Çözümleme Yöntemi’nde önce anlamlı bir bütün olarak cümleler verilir ve daha sonra kelime, hece gibi parçalara gidilir.

2004-2005 öğretim yılında ise Milli Eğitim Bakanlığı ve Talim ve Terbiye Kurulu Başkanlığı’nca Çoklu Zeka, Yapılandırmacı Yaklaşım, Beyin Temelli Öğrenme, Bireysel Farklılıklara 
Duyarlı Öğretim gibi yaklaşım ve modeller çerçevesinde geliştirilen yeni Türkçe Öğretim Programı’nda yöntem olarak Ses Temelli Cümle Yöntemi’nin kullanılması ön görülmüş ve 120 pilot okulda denemeleri yapılarak, 2005-2006 öğretim yılından itibaren uygulanmaya konulmuştur (Arslantaş, \& Cinoğlu, 2010).

Ses Temelli Cümle Yöntemi’nde seslerden hecelere, hecelerden kelimelere, kelimelerden cümlelere ulaşılmaya çalışılmaktadır. Öğretilecek sesler öğretim sırasına göre gruplanmış ve yeni hece ve kelimeler bu ses gruplarına uygun olarak oluşturulmaya çalışılmıştır. Ses grupları ise sırasıyla şu şekildedir. 1. Grup: e, l, a, t ; 2. Grup: i, n, o, r, m ; 3. Grup: u, k, l, y, s, d ; 4. Grup: ö, b, ü, ş, z, ç ; 5. Grup: g, c, p, h ; 6. Grup: ğ, v, f, j.

Okuma yazma öğretiminde kullanılan yöntemlerin okuma ve yazma becerilerini geliştirme, okuryazar bireyler yetiştirme gibi amaçlara hizmet edip etmediğini araştıran birçok çalışmaya rastlamak mümkündür. Literatür incelendiğinde uygulanan diğer ilk okuma ve yazma öğretim yöntemleri gibi yazma Ses Temelli Cümle Yöntemi ile ilgili olarak yapılmış birçok çalışmaya rastlanmaktadır. Bu çalışmalar arasında yöntemin olumlu yanlarına vurgu yapan çalışmaların yanında olumsuz sonuçları ve/veya eksik yanlarını ifade eden çalışmalar da vardır. Yapılan bazı çalışmalarla durumu özetlemek gerekirse;

Güneş (2005) Ses Temelli Cümle Yöntemi’nin Türkçe’nin yapısına uygun olduğunu, bu yöntem ile ilk okuma yazma öğretiminde öğrencilerin; grup halinde ve kısa süreli okumayazmada öğrenmeye geçtiklerini, düzgün el yazısı yazdıklarını, dikkat ve anlama düzeylerinin arttığını ve öğrenme sürecinde aktif olduklarını ifade etmiştir. Demirel (2006), Ses Temelli Cümle Yöntemi’nin öğrencilerin gelişim düzeylerine uygun olduğu ve özgüvenlerini arttırdığını ifade etmiştir. Ferah (1999) ise Türkçe'nin en önemli özelliklerinden harflerin seslerle bire bir eşleşmesi ve her harfin kendine ait bir sesinin olması, okunduğu gibi yazılan ve yazıldığı gibi okunan bir dil olması nedeniyle Ses Temelli Cümle Yöntemi'nin olumlu yönlerine vurgu yapmıştır. Turan, \& Akpınar (2008) yapmış oldukları araştırma sonucuna göre Ses Temelli Cümle Yöntemi’nin erken okumayı sağlama, ezberci olmama, öğrenci merkezli olma ve kolay öğrenilebilir olma gibi yönlerden açılarından etkili olduğu sonucuna ulaşmışlardır. Buna karşın Bilir (2005) Ses Temelli Cümle Yöntemi’nin çocuğun gelişimine ve psikolojisine aykırı olduğunu, çocuğun toptan algılama ilkesi ile çeliştiği ve dolayısıyla gözün ses takılmasından dolayı okuma hızını yavaşlattığını bu nedenle de yöntemin çocukların öğrenme özelliklerine değil de daha çok, ayrıntıları görme ve aralarında mantıksal bağ kurma becerileri gelişmiş yetişkinler için uygun bir yöntem olduğunu bu yöntemle okuma yazma öğrenen çocuk için ortaya çıkan sonucun anlamlı bir okuma olmayıp, yalın bir seslendirme olduğunu belirtirken, (Beyazıt, 2007) Aldemir (2005), Ses Temelli Cümle Yöntemi ile öğrenen öğrencilerin okuma kalitesinin düştügünü, heceleme hatası yaptıklarını, akıcı okuyamadıklarını, sessiz okumada ve okuduklarını anlamada sorunlar yaşadıklarını ifade etmiştir. Benzer şekilde Şahin, İnci ve Turan (2006)'ın yapmış olduğu araştırmada ise Ses Temelli Cümle Yöntemi ile yapılan öğretimde öğrencilerin daha fazla ekleme hatası yaptıkları sonucuna ulaşılmıştır. Güzel Özmen ve Doğan (2011) yapmış oldukları araştırmada ise Ses Temelli Cümle Yöntemi ile okuma yazmayı öğrenen öğrencilerin Çözümleme Yöntemi ile okuma yazma öğrenen öğrencilere göre daha çok okuma hataları yaptıkları sonucuna ulaşmışlardır. Korkmaz’ın (2007) yaptığı araştırmada da, Ses Temelli Cümle Yöntemi ile okuma yazma öğretiminde "öğrencilerin hızlı okumada, anlamlı okumada ve cümle kurmada zorlandıkları” sonucuna ulaşılmıştır.

\section{Araștırmanın Önemi}

Bu çalışmada Ses Temelli Cümle Yöntemi’nin olumsuz yönlerini ele alan çalışmalardan yola çıkılarak bu olumsuzlukların nedenleri araştırılmaya çalışılmıştır. Yapılan literatür taramalarında 
da yaşanılan olumsuzlukların nedenlerinin araştırılmadığı, yapılan çalışmaların ise sorunu yalnızca yöntemle ilişkilendirilen sonuç odaklı ve birçoğu da öğretmen görüşlerine dayalı betimsel çalışmalar olduğu dikkat çekmektedir.

Bu çalışmalarda Ses Temelli Cümle Yöntemi, okuma hatalarına sebep olması, çocuğun, yavaş ve heceleyerek ve duraksayarak okumasına neden olması gibi yönlerden eleştiriler yer almaktadır. Oysa okuma yazma öğreniminde sonuç kadar yöntemin olumlu veya olumsuz sonuçlanmasının ardındaki nedenler de önemlidir. Yaşanan olumsuzluklar yöntemle doğrudan ilişkili olabileceği gibi yöntemle ilişkili veya yöntemden bağımsız birçok faktörün etkisi ile ortaya çıkmış olabilir. Bu nedenle bu çalışmada "Ses Temelli Cümle Yöntemi” ile ilk okuma ve yazma öğretiminde öğrencinin anlamlı okumasını etkileyebilecek unsurlar ve etkileri belirlenmeye çalışılmıştır.

\section{Problem}

$\mathrm{Bu}$ araştırmada "Ses Temelli Cümle Yöntemi ile ilk okuma yazma öğretiminde öğrencinin anlamlı okumasını etkileyen unsurlar nelerdir?” sorusuna cevap aranmaya çalışılmıştır.

Öğrenme bireyin ön yaşantıları ve bireysel farklılıkları gibi iç koşulları ile eğitim durumları gibi dış koşulların etkisindedir. Eğitim durumu belirlenmiş bir zaman birimi içinde bireyi etkileme gücünde olan dış koşullardır. Eğitim durumunda hedefin gerektirdiği içerik, öğretmen, araç-gereç ve kaynaklar ile yöntem bulunması gerekli öğelerdir (Bilen, 1999). Okuma bir öğrenme sürecidir ve bu süreç birçok faktörün etkisindedir. Bu nedenle de öğrenmeyi etkileyen unsurlar dikkate alınmıştır. Kaya (2012), öğrenmeyi etkileyen unsurları; öğrenenle ilgili (türe özgü hazıroluş, olgunlaşma, uyarılmışlık, kaygı, eski yaşantılar, güdü), öğrenme yöntemiyle ilgili (öğrenme zamanı, öğrenilecek alanın yapısı, katılma, geribildirim), öğrenilecek olanla ilgili (algısal ayırt edicilik, anlamsal çağrışım, kavramsal gruplandırma) şeklinde ifade etmiştir. Ses Temelli Cümle Yöntemi ile gerçekleştirilen ilkokuma- yazma öğretimini tek başına yöntemin etkisiyle değerlendirmek yerine bu çoklu değişkenlerin de etkisine bakılmasının yerinde olacağı düşünülmüştür. Bu nedenle öğrencilerin anlamlı okumasının önündeki olası etkenlerin tek tek incelenmesi gereğiyle bu çalışmada öğrenci, kullanılan yöntem, yöntemin uygulayıcısı olarak öğretmen, kullanılan ders araç-gereçleri ve aile açısından soruna yaklaşılmıştır.

Araştırmada aşağıdaki alt sorulara yanıt aranmıştır.

Anlamlı okuma sürecini;

1) Öğrenci özellikleri nasıl etkilemektedir?

2) Yöntem nasıl etkilemektedir?

3) Yöntemin uygulayıcısı olarak öğretmen ve öğretim uygulamaları nasıl etkilemektedir?

4) Kullanılan ders materyalleri nasıl etkilemektedir?

5) Aileler nasıl etkilemektedir?

\section{Yöntem}

Araştırma verileri nitel araştırma yöntemlerinde kullanılan doküman incelemesi, gözlem ve görüşme yöntemleri yoluyla toplanmıştır. Araştırmanın geçerliliğini artırmak amacıyla çalışılan araştırma problemiyle ilişkili yazılı ve görsel materyal ve malzemelerin incelenmesi anlamına gelen Best'in (1959, akt. Karasar, 2007) “mevcut kaylt ya da belgelerin, veri kaynağı olarak, sistemli incelenmesi” olarak ifade ettiği doküman incelemesi sürecinde ilk okuma ve yazma öğretiminde kullanılan yazılı dokümanlar incelenmiştir. Ders kitapları ya da materyalleri örneği ele alındığında doküman verisi sayıca çok olduğunda araştırmacı örneklem seçme yoluna gidebilir (Yıldırım, \& Şimşek, 2008). Bu nedenle araştırmada örneklem seçme yoluna gidilmiş 
ve Bolu ili ilköğretim okulları arasından basit şans yoluyla seçilmiş bir ilköğretim okulunda 2012-2013 öğretim yılında okutulmak üzere Talim Terbiye Kurulu’nun okuma-yazma öğretimi için onay verdiği okuma yazma öğretimi ders kitabı, o okulda zümre öğretmenleri tarafından yardımcı kaynak olarak seçilmiş bir okuma seti ve yine aynı zümre öğretmenleri tarafından hazırlanmış ya da kullanılmak üzere çeşitli kaynaklardan aldıkları çalışma yapraklarıdır. Doküman incelemesi sonucunda Türkçe’ye ses ve anlam açısından uygun olmadığı düşünülen hece, kelime veya cümleler "Aşă̆ıda verilen yapıları Türkçe'ye uygunluk açısından değerlendirdiğinizde ne söylersiniz? sorusuyla Tablo 2'de sunulduğu şekliyle 3 Türkçe eğitimi uzmanı ve 3 ilkokuma-yazma öğretimi alanlarında uzmanlaşmış toplam 6 uzmanın görüşüne sunulmuş ve ilgili veriler sunulurken uzman görüşlerinden yararlanılmıştır. İlgili veriler sunulurken uzman görüşleri T1, T2, T3, T4, T5, T6 şeklinde kodlanarak sunulmuştur.

Araştırmada kapsamında yine aynı okulun seçkisiz örneklem yoluyla seçilmiş bir birinci sınıf şubesi öğretmeni ile "Ses Temelli Cümle Yöntemi ile ilk okuma yazma öğretiminde karşılaştığınız sorunlar ve yaşadığınız sıkıntılar nelerdir, sebepleri sizce neler olabilir?” sorusu etrafında; öğrencilerin aileleri ile de kişisel bilgilerinin yanında "Çocuğunuzun okuma yazma öğretimi süresince karşılaştığınız sorunlar veya yaşadığınız zorluklar nelerdir?” gibi iki açık uçlu soru yoluyla görüşmeler gerçekleştirilmiştir. Yapılan görüşmeler esnasında görüşülen velilerin ifadeleri araştırmacı tarafından doğrudan not edilerek kayıt altına alınmıştır. Çocuklarının okuma ve yazma sürecini destekleme konusunda sıkıntı yaşadıklarını ifade eden velilerin çocuklarının okuma yazma öğretimi süreci sınıf içinde doğrudan gözlenmiş ve çocukların okuma yazma öğrenim sürecinde yaşadıkları sıkıntılar ve nedenleri belirlenmeye çalışılmıştır.

Araştırmada okuma ve yazma öğretimi açısından sıkıntı yaşayan öğrenciler arasından basit şans yoluyla seçilmiş 10 öğrencinin okuma yazma becerileri gözlenmiştir. Öğrenciler ile bulgular sunulurken FY, DC, OÖ, ZS, ÇT, ÖK, TA, KK, DK, YD şeklinde isim ve soy isimlerinin kısaltmaları ile verilmiştir.

Araştırma kapsamında veli görüşlerinden hareketle okuma yazma öğrenim süreci gözlenen ve okuma ve yazma öğrenirken sıkıntı yaşadığı görülen 10 çocuğun gelişim özellikleri incelenmiş velilerin çocukların özelliklerine ilişkin bilgi alınmış, ayrıca yaşına uygun kilo ve boy ölçülerine sahip olup olmadığı kontrol edilmiştir. Çocukların ölçümleri yapılmadan önce, üzerlerindeki kalın giysiler ile ayakkabıları çıkartılmış vücut ağırlığı ölçümü, elektronik baskül kullanılarak gerçekleştirilmiştir. Boy ölçümü ise esnemeyen plastik bir mezüre kullanılarak araştırmacı tarafından alınmıştır. Öğrencilerin yaşına uygun boy ve kilo ölçüleri için Neyzi, Günöz, Furman, Bundak, Gökçay, Darendeliler ve Baş (2008)'ın yapmış olduğu Türk Çocuklarında Vücut A Ăırlı̆̆ı, Boy Uzunluğu, Baş Çevresi ve Vücut Kitle İndeksi Referans Değerleri adlı çalışmada yer verilen ölçüler ile kullanılmıştır.

\section{Bulgular ve Yorumlar}

Aşağıda doküman incelemesi, görüşme ve gözlemler sonucunda elde edilen bulgulara yer verilmiştir. İlgili veriler sunulurken öğrencinin hızlı ve anlamlı okuma ve yazmasını etkileyeceği düşünülen öğrenci özellikleri, kullanılan yöntemin özellikleri, yöntemin uygulayıcısı olarak öğretmen özellikleri ve öğretim uygulamaları, kullanılan ders araçları ve veliler olmak üzere altı farklı değişkenin etkileri tartışılmıştır.

\section{1. Öğrenci Özelliklerine İlişkin Bulgular}

Araştırma kapsamında incelenen birinci sınıf şubesinde $17 \mathrm{klz}$ ve 8 erkek olmak üzere 25 öğrenci bulunmaktadır. Bu öğrencilerden 8’i 60-66 aylık, 13’ü de 66-72 aylık çocuklardır. Bu öğrenciler Piaget'in işlem basamakları açısından bakıldığında somut işlemler döneminde olan çocuklardır. 
Tablo 1. Çocukların Yaş, Bireysel Farklılıkları, Boy, Vücut Ağırlığı.

\begin{tabular}{|c|c|c|c|c|c|c|c|}
\hline \multirow{2}{*}{ : } & \multirow{2}{*}{ 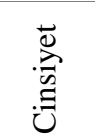 } & \multirow[b]{2}{*}{$\underset{\pi}{\pi}$} & \multirow[b]{2}{*}{ Bireysel farklılık } & \multicolumn{2}{|c|}{ Vücut Ağırlığg (kg) } & \multicolumn{2}{|c|}{ Boy Uzunluğu } \\
\hline & & & & $\begin{array}{l}\text { Ortalama } \\
\text { beklenen }\end{array}$ & $\begin{array}{l}\text { Vüicut } \\
\text { ağırlığı }\end{array}$ & $\begin{array}{l}\text { Ortalama } \\
\text { beklenen }\end{array}$ & $\begin{array}{c}\text { Boy } \\
\text { uzunluğu }\end{array}$ \\
\hline FY & Kız & 65 aylık & $\begin{array}{l}\text { Anne-baba ayrı. } \\
\text { Öğrenme isteği yok }\end{array}$ & 18.4 & 18 & 109.1 & 108.7 \\
\hline DÇ & Erkek & 64 aylık & Çok zayıf & 18.6 & 15 & 110.4 & 106.6 \\
\hline ОÖ & Erkek & 65 aylık & Gözlük kullanıyor. & 18.6 & 17.5 & 110.4 & 109 \\
\hline $\mathrm{ZS}$ & Kız & 67 aylık & Çok zayıf. & 19.5 & 16.5 & 112.1 & 111 \\
\hline ÇT & Erkek & 69 aylık & $\begin{array}{l}\text { Çok hareketli. } \\
\text { Konsantrasyon problemi var. }\end{array}$ & 19.6 & 18 & 113.3 & 110 \\
\hline ÖK & Erkek & 64 aylık & $\begin{array}{l}\text { Artikilasyon sıkıntısı var. "r" } \\
\text { sesi yerine “y” sesi kullanıyor. }\end{array}$ & 18.6 & 17 & 110.4 & 108.2 \\
\hline TA & Kız & 66 aylık & Okula gelmek istemiyor. & 19.5 & 18.5 & 112.1 & 110.3 \\
\hline KK & Kız & 68 aylık & $\begin{array}{l}\text { Artikilasyon sıkıntısı var. ş, t, } \\
\text { k gibi sessizleri çıkarmakta } \\
\text { zorlanıyor. }\end{array}$ & 19.5 & 19.5 & 112.1 & 115 \\
\hline DK & Erkek & 63 aylık & $\begin{array}{l}\text { Annesine çok bağlı ve bağımlı } \\
\text { sürekli ağlıyor. Okuldan } \\
\text { gitmek istiyor }\end{array}$ & 18.6 & 16 & 110.4 & 107 \\
\hline YD & Kız & 73 aylık & $\begin{array}{l}\text { Kulaklarından rahatsız } \\
\text { kulaklık kullanıyor. }\end{array}$ & 20.6 & 18 & 115.1 & 113 \\
\hline
\end{tabular}

Bu çocukların özellikle duygusal, fiziksel ve dil gelişimi açısından okul öğrenimlerine hazır olmamalarının anlamlı okuma sürecini olumsuz etkilediği sonucuna ulaşılmıştır.

\section{Yönteme İlişkin Bulgular}

\section{a. Yöntemin yapısal özelliğine ilişkin bulgular}

Ses Temelli Cümle Yöntemi’nde öğretime seslerden başlanması öngörülmüştür (MEB, 2005). Öğretime seslerden başlanması yöntemin başlıca yapısal özelliğidir. Yönteme göre sesten heceye heceden de kelimeye aşağıda gösterildiği şekilde ulaşılmaktadır.

\begin{tabular}{lll}
\hline $\mathrm{e}+\mathrm{l}$ & el+e & ele \\
\hline $\mathrm{a}+\mathrm{n}$ & an $+\mathrm{a}$ & ana \\
\hline $\mathrm{a}+\mathrm{t}$ & $\mathrm{at}+\mathrm{a}$ & Ata \\
\hline
\end{tabular}

Örneğin "ele" kelimesine nasıl ulaşılacağı ise http://www.mebk12.meb.gov.tr web adresinde şu şekilde açıklanmaktadır.

“el” kelimesi gösterilerek ögrrencilerden okumaları istenir. “e” sesi gösterilerek okumaları istenir. Önce "el" sonra "e" sesi aralarında boşluk bırakılmaksızınyazılarakoluşan yeni kelimenin nasıl okunabileceği sorulur. Öğrencilerin okuma denemelerinin ardından doğru okumayı yaparak tekrarlamaları istenir. "el" kelim esine "e" sesi eklenerek oluşturulan yeni kelime hecelemeden okunmalıdır”.

Ses Temelli Cümle Yöntemi ile ilk okuma ve yazma öğretiminde yukarıdaki örneklerde de görüldüğü gibi çözümlemeler yapılırken Türkçe’nin sondan eklemeli bir dil olması nedeniyle gramer olarak doğru gibi görünse de anlam olarak yanlış çözümlemeler de üretilebilir. Örnek incelendiğinde el + e şeklindeki bir heceleme Türkçe’ye uygun değildir. Çünkü Türkçe'de kelime içinde iki ünlü arasındaki ünsüz, kendinden sonraki ünlüyle hece kurar: a-ra-ba, bi-çi-mi- 
ne, in-sa-nın, ka-ra-ca vb. Kelime içinde yan yana gelen iki ünsüzden ilki kendinden önceki ünlüyle, ikincisi kendinden sonraki ünlüyle hece kurar: $a l-d l$, bir-lik, sev-mek vb. Kelime içinde yan yana gelen üç ünsüz harften ilk ikisi kendinden önceki ünlüyle, üçüncüsü kendinden sonraki ünlüyle hece kurar: alt-lık, Türk-çe, kork-mak vb. (www.tdk.gov.tr).

Ses Temelli Cümle Yöntemi’nin yapısı gereği okuma öğrenme sürecinde ses ve harften hareket edildiği için gözün satır üzerinde doğal olandan daha kısa bir alanı görmesine neden olabilir. Böylece de heceleyerek okuyabilmektedir. Bu durum ise anlamlı okuma açısından sakıncalı olabilmektedir. Doğru yapılandırılmayan öğretim süreci ile Ses Temelli Cümle Yöntemi doğal olarak hecelemeyi gerektirir. Bu ise okuma yazma sürecinde hiç yapılmayacak bir şeydir (Beyazıt, 2007). Çocuk heceleyerek okuduğu için anlamlı bütüne değil de heceye odaklanmakta, kazandığı anlam varsa bile sık sık dönüşler sebebiyle onu kaybetmektedir. Dolayısıyla da gözses uzaklığı yeterli düzeye ulaşamaz. Göz yazı üzerinde sıçramayı ne kadar büyük yaparsa, okuma hızı ve buna bağlı olarak anlama da o kadar hızlı olur. Çocuğun gözünün, yazı üzerinde yapacağı sıçrama, kelimeleri oluşturan seslere odaklanırsa, göz, kelime üzerinde inişli çıkışlı sıçrama yapacağından, kelimeyi okurken, sıçramada geçen sürenin uzunluğu, kelimenin başı ile sonu arasında kurulacak anlam bütünlügüünü kaybolmasına neden olur. (Tok, Tok, \& Mazı, 2008). Belirtilen sakıncalar zaman içerisinde bireylerin çabaları ile aşılabilir. Ancak başlangıçta kazanılan olumsuz okuma alışkanlıkları, ömür boyu hızlı ve anlamlı okumayı engelleyebilir (Güleryüz, 1991; Binbaşığlu, 2005).

Yapılan gözlemlerde de yanlış hecelemelerin anlamlı, akıcı ve düzgün okuma açısından olumsuz sonuçlara neden olduğu gözlenmiştir. Yanlış hecelemeler konusunda "ele" örneği ele alınacak olursa yapılan gözlemlerde ele kelimesini $e l$ - $e$ şeklinde okuduğu ve yanlış heceleme nedeniyle sese odaklandığı gözlenmiştir. Çocuğun $\underline{e l+e}$ şeklinde öğrendiği kelimeyi $\underline{e+l e}$ şeklinde hecelemesi beklenmektedir. Yanlış heceleme aslında bu uygulamadan kaynaklanmaktadır. Aslında eklemeler yapılırken Türkçe'nin ses yapısı gereği "le" açık hecesine ulaşılarak "ele" yapılmalıdır (Çiftçi, Yüksel, Mühürcüoğlu, \& Yılmaz, 2005).

\begin{tabular}{|c|c|c|c|c|}
\hline$a+n$ & an & $a n+a$ & ana & Heceleme yanlışı çocuğun kök ve ek kavramları konusunda \\
\hline $\mathrm{o}+\mathrm{n}$ & on & $o n+a$ & Ona+t & lemlerde de öğrencilerin kök ve ekleri avırt edemedikleri. \\
\hline
\end{tabular}
hecelemeleri istendiğinde ise kelimeyi hecelere ayıramadıkları görülmüştür.

Örneğin "Ela inat, Lale inat” cümlesinde öğrencilerin "inat” kelimesini yanlış heceleyerek okudukları için anlamını da karıştırmakta oldukları gözlenmiştir "inat” kelimesini "in- at" şeklinde okudukları için cümle içinde verildiğinde gözlenen öğrencilerden ZS “Ela ve Lale’nin attan inmelerini istiyoruz" demiştir.

“Onat” kelimesi incelendiğinde de yine kelimeye; on- ona- onat şeklinde ulaşılması anlam kargaşasına neden olmuştur. Kelime Türkçe kök ek ilişkisi açısından incelendiğinde Onat ek almış bir kelime değildir. Kelimenin kökü "ona” değildir. Ya da "ona”, “on” kökünden türemiş bir kelime değildir. Bu türden bir kullanımda kök ve ek açıkça görünmemektedir. Bu nedenle yapılan birleştirme Türkçe’nin yapısına aykırı görülmektedir.

\section{b) Yöntemin Öğrenme Yaklaşımına Uygunluğuna İlişsin Bulgular}

Ses Temelli Cümle Yöntemi MEB (2005)’te belirtildiği üzere yapılandırmacı öğrenme yaklaşımına dayandırılmaktadır. Yapılandırmacı yaklaşıma göre hazırlanmış olan Türkçe Öğretim Programına göre, öğrenci bütün etkinliklerde aktif rol almalıdır. Bu nedenle, etkinliklerin, öğrencinin iletişim kurma, yaratıcılık, iş birliği yapma, sorun çözme, girişimcilik gibi becerilerini geliştirecek şekilde yapılandırılmış olduğu ifade edilmekte, öğrencilerin dil ve zihin becerilerini 
geliştirme amacıyla Türkçe’yi doğru, etkili ve güzel kullanma, eleştirel düşünme, yaratıcı düşünme, iletişim, problem çözme, araştırma, bilgi teknolojilerini kullanma, girişimcilik, karar verme, metinlerarası okuma, kişisel ve sosyal değerlere önem verme gibi özelliklere vurgu yapılmaktadır. (MEB, 2005). Yapılan doküman incelemesinde "Ali itaat et.", "Ali er ol." şeklinde ifadelere rastlanmıştır. Bu tür ifadelerin kullanıldığı bir öğretim süreci yapılandırmacı öğrenme yaklaşımı felsefesine ters düşmektedir Çünkü yukarıda verilen örneklere bakıldığında eleştirel düşünen, yaratıcı düşünme, karar verme gibi özellikleri geliştirilmek istenen öğrenciye, daha öğrenme hayatının başlangıcında bu türden ifadelerin verilmesi sakıncalı görülmektedir. Bu durum da yapılandırmacı yaklaşımla hazırlanmış olan ilk okuma yazma öğretimi ile çelişen yanlış uygulamalara örnek olarak verilebilir.

Ayrıca öğretimde çocuğun seviyesine uygun olmayan kelime türleri de kullanılmaktadır. Oysa yapılandırmacı yaklaşımda, çocuğun dış dünyadan aldığı nesne, olgu ya da kavrama ilişkin bilgileri, daha önceki deneyimlerine bağlı olarak yapılandırması ve yorumlanması söz konusu iken, tek başına bir anlam ifade etmeyen seslerle böyle bir oluşumun gerçekleşmesinin zor olacağı bilinmektedir (Gündüz, 2006).

\section{3) Yöntemin Uygulayıcısı Olarak Öğretmen ve Öğretim Uygulamalarına İlişkin Bulgular}

Araştırma kapsamında tesadüfi örneklem yoluyla seçilmiş olan sınıf şubesinin öğretmeni, 43 yaşında sınıf öğretmenliği 1993 lisans mezunu, 20 yıllık öğretmenlik deneyimi bulunan erkek öğretmendir. Yapılan görüşmelerde sınıf öğretmenine Ses Temelli Cümle Yöntemi ile ilk okuma yazma öğretiminde yaşadığı sıkıntılara ilişkin sorulan açık uçlu soru aracılığıyla sınıf öğretmeni ile ilgili olarak şu bilgilere ulaşılmıştır.

Sınıf öğretmeni, Ses Temelli Cümle Yöntemi ile okuma yazma öğretimine yönelik bir eğitim almamıştır. Sınıf öğretmeni ilk okuma yazma öğretimine ilişkin lisans ders ve uygulamalarında İlk Okuma yazma öğretiminde kullanılan öğretim yöntemlerine ilişkin genel bilgiler yanında temel olarak Çözümleme Yöntemi ve uygulamalarına ilişkin eğitim aldığını ve 2005 yılına kadar öğretim uygulamamalarını da Çözümleme Yöntemi ile gerçekleştirdiğini belirtmiştir. Ses Temelli Cümle Yöntemi’ne geçiş sürecinde ise yalnızca 15 günlük yöntemin tanıtıldığı bir hizmet içi eğitim programına katıldığını ancak bu süreyi de yöntemi uygulama açısından yeterli görmediğini ifade etmiştir. Bu açıdan bakıldığında sınıf öğretmeninin Ses Temelli Cümle Yöntemi ile öğretim yapabilecek yeterliliğe sahip olmadığı söylenebilir.

Sınıf öğretmeninin hazır ders materyalleri ile öğretim yapması ve materyal seçiminde seçici davranmaması nedeniyle de öğrencilerin anlamlı okuma açısından sıkıntı yaşadıkları söylenebilir. Sınıf öğretmeni teknolojinin gelişimi ile birlikte hazırlanmış bilgisayar destekli öğretim programları sayesinde ses öğretimini yapabildiğini bu sayede işinin daha kolaylaştığını ancak derslerini teknoloji desteğiyle gerçekleştirmesine rağmen öğrencilerin okuma ve yazmada sıkıntı yaşamalarına anlam veremediğini ifade etmiştir. Ancak öğretmen sesleri kendisi seslendirmek yerine hazır materyal seçme yoluna gitmiştir. Sözü edilen bu teknoloji destekli okuma yazma öğretim programında çocuk için zaten soyut olan seslerin ayırt ediciliğinin azaldığı ve dolayısıyla öğrenci tarafından anlaşılmasının da zorlaştığı ve özellikle "m” ve " $n$ ", “t-d" "p-b” "z-s” gibi seslerin birbirine karıştırıldığı gözlenmiştir. Bu durum da öğrencinin okuması önünde bir engel olarak görülmüştür.

Sınıf öğretmeni, yardımcı kaynak olarak kararlaştırılan okuma setini kendisinin çok fazla incelemediğini zümre arkadaşlarının içinde çok sayıda örnek olması açısından beğendikleri okuma setini kendisinin de onayladığını, ayrıca çalışma yapraklarını da çoğunlukla ilk okuma yazma öğretimine yönelik olarak hazırlanmış kaynaklardan indirdiğini ifade etmiştir. Sınıf 
öğretmeninin kendi ifadelerinden yola çıkarak öğretimde kullandığı ders materyalleri ile ilgili olarak bu türden bir değerlendirme yapmadığı öğrencisine sunduğu ders araç gereçlerini belirlerken "öğrenciye görelik, anlamlılık" (Çelik, 2012) gibi ilkelere dikkat etmediği söylenebilir. Örneğin öğrenciye uygunluk ilkesine göre kullanılacak araç, öğrencilerin özelliklerine (yaş, zeka ve geçmiş yaşantıların düzenine) uygun olmalıdır. Anlamlılık ilkesine göre de bir malzeme ne kadar anlamlı ise öğrenilmesi o kadar kolaydır. Anlamlı sözcüklerin öğrenilmesi anlamsız hecelerin öğrenilmesine oranla daha kolaydır (Çelik, 2012). Bu durumunda öğrencinin hızlı ve anlamlı okumasını engelleyen bir faktör olabileceği söylenebilir.

\section{4) Kullanılan Ders Materyallerine İlişkin Bulgular}

Araştırmanın bu boyutunda öğrenmeyi etkileyen faktörler arasında sayılan "öğrenilecek olanla ilgili etmenler” in neler olabileceğine ilişkin olarak ilk okuma ve yazma öğretimi için Milli Eğitim Bakanlığı Talim ve Terbiye Kurulu tarafından onaylı ders kitabı ve öğretimde kullanılan yardımcı kaynaklardaki (okuma seti, çalışma yaprakları) metinler ses-hece-kelime ve cümle bağlamında incelenmiş ve öğrencilerin anlamlı okuma süreci ile ilişkilendirilmiştir. 22'de incelemeler sırasında dilbilgisi ve anlam açısından Türkçe öğretimine uygun olmadığı düşünülen ve öğrencilerin anlamlandırmakta zorlandıkları ifadeler yer almaktadır.

\section{a. Kullanılan İfadeler Türkçe Dilbilgisine Uygunluk Açısından İncelendiğinde;}

Ders materyallerinde kullanılan ifadelerin yöntemin yapısı ile ilişkili ses, hece, ek kök, kelime oluşturma süreçleri ile ilgili yöntemin yapısı ile ilgili bulgularda da belirtilen yanlışlara rastlanmıştır.

Tablo 2. Dil bilgisi ve anlam açısından uygun bulunmayan ifadeler

\begin{tabular}{|l|l|}
\hline E & El \\
\hline L & El+e -ele \\
\hline A & El+a - ela \\
\hline Ela inat, Lale inat. & Ela lale el etti. \\
\hline Ela el etti. & Ali teli itti. \\
\hline Et al, et at. & Oltan tam elma tat. \\
\hline Ela atleti at. & Ali aleti ne ettin? \\
\hline İnan eline tel al. & Leman orman al. \\
\hline Umut unu tut. & Annem omo arar. \\
\hline Ayna al, kaya tak. & Altan mola al. \\
\hline Talat el et. & Etli ekmek etti. \\
\hline Et al, et at. & Altan tane tane et al. \\
\hline Ali eti itti. & Nil telli et al. \\
\hline Ali et al, et tat. & Nail ata nal at. \\
\hline Talat ata elle. & Ela tel atla. \\
\hline Nalan nine anlat. & İki tane nane al. \\
\hline Ela ile lale elti. & Onat on ton ot al. \\
\hline Ali eti 7. & Ata eti \\
\hline Ali tatili 7. & Ela 7’li anlat. \\
\hline Ali er ol. & Ali itaat et. \\
\hline Nil telli et al & Ali, Atilla el ele teli al. \\
\hline İl il lale al. & Altan tane tane et al. \\
\hline al, atlet, telli. & Altan annene ninni anlat. \\
\hline
\end{tabular}

Tablo 2'de verilen örnekleri (yöntemin özelliği nedeniyle ses-hece-kelime ve cümle yapılarını), Türkçe ses ve anlam yapısına uygunluğu açısından inceleyen uzmanlar, okuma yazma öğretiminin amacının yalnızca okumak değil, Türkçe öğretiminin temelini oluşturmak olduğunu, kullanılan ifadeleri de Türkçe öğretimi açısından uygun bulmadıklarını ifade etmişlerdir. Uzmanlar; kullanılan ifadeleri ölçünlü dile uygun bulmamışlardır. Oluşturulan hece yapılarını biçimbilim alanına göre değerlendirdiklerinde bu tür kullanımların yanlış olacağını belirtmişlerdir. Örneğin görüşü alınan uzmanlardan T5 görüşünü şu şekilde ifade etmiştir.

"Seslem (hece) bölme süreci dil edinim sürecinde kazanılır. Uygulama edinim süreciyle çelişmektedir. Böyle bir uygulamada çocuk yalnızca heceye takılıp okuma hızı yavaşlamaz aynı zamanda yanlış heceleme ile de uğraşacağı için okuma hızı daha da düşebilir”. 
Cümle yapılarının da Türkçe’nin dilbilgisi kurallarına uygun olmadığını belirtmişlerdir. Örneğin konu ile ilgili görüşü alınan T6 "Talat ata elle” cümlesi için;

"İsmin halleri yanlış kullanılmıştır, burada bir yönelme söz konusu değildir fakat ismin -e hali- yönelme hali kullanılmıştır. Atı elle şeklinde bir kullanımı dilbilgisi açısından daha doğru olacaktır. Sesler belli bir sıra ile verilecekse sırası beklenmelidir. Yanlış kullanımlara gidilmemelidir. "Böylesine yanlış bir kullanım sonrasında ismin halleri çocuğa nasıl doğru bir şekilde kavratılır bilemiyorum. Yanlışı doğruya döndürmek her zaman ilk anlatımdan zordur" demiştir.

Örneğin "Ela inat, Lale inat” cümlesi ile ilgili olarak da uzmanlardan T3 cümlede kullanılan “inat” kelimesinin ölçünlü dile uygun olmadığını bir niteleme sıfatı olarak “inatçı” şeklinde kullanılması gerektiğini ve bir sıfat olduğunu "inat” şeklinde yalnızca yerel kullanımda yer alabileceğini belirtmiş, Türkçe öğretiminin Türkçe’yi doğru kullanan bireyler yetiştirme amacı ile ters düssen bir kullanım olduğunu ifade etmiştir.

\section{b. Kullanılan İfadeler Anlam Açısından İncelendiğinde,}

Yanlış heceleme, anlamı bilinmeyen sözcükler, eş sesli sözcüklerin bir arada kullanımı, görsellerin yanlış kullanımının anlam bozukluklarına neden olduğu ve bu durumunda hızlı ve anlamlı okumayı olumsuz etkilediği gözlenmiştir. İncelenen dokümanlarda mantıksal, yaygın ve standart dil (ölçünlü dil) kullanımı açısından anlamlı bulunmayan ifadelere rastlanmıştır. Görüşüne başvurulan uzmanlar ise okuma yazma öğretiminde farklı yöntemler kullanılabileceğini ve okuma yazma öğretilebileceğini ortaya çıkan sorunların, yöntemin felsefesinden ya da çıkış noktasından değil de uygulama yanlışlarından kaynaklanabileceğini belirtmişlerdir. Ayrıca öğretimde kullanılan bu ifadelerin okumanın anlama boyutundan çok seslendirme boyutuna hizmet ettiğini ve dolayısıyla cümlelerin okuduğunu anlayan ve Türkçe'yi doğru kullanan bireyler yetiştirme amacına hizmet etmediği görüşündedirler. Uzmanların ders materyallerinde kullanılan ifadelerin Türkçe’ye uygunluğu hakkında görüşleri Tablo 3’degörülmektedir.

Tablo 3. Öğretimde kullanılan cümleler ile ilgili uzman görüşleri

\begin{tabular}{|l|l|}
\hline Altan tane tane et al. & $\begin{array}{l}\text { T5 “tane tane et nasıl alınır, çocuğa daha sonra kilogram kavramı nasıl } \\
\text { anlatılır? }\end{array}$ \\
\hline Ayna al, kaya tak. & T3 “kaya nasıl takılır?, T1 ‘kaya takılacak bir şey midir?” \\
\hline Naneleri ertele. & $\begin{array}{l}\text { T4 “naneleri ertelemek” ne demektir? Böyle bir kullanıma daha önce } \\
\text { hiç rastlamadım. Program mı bu ertelensin?” }\end{array}$ \\
\hline Oltan tam elma tat. & $\begin{array}{l}\text { T2” tam elmanın tadı başka mıdır?, ayrıca tadılan elma mı dır, elmanın } \\
\text { tadı mıdır?” }\end{array}$ \\
\hline Altan mola al. & $\begin{array}{l}\text { T4 “Türkçe’de mola almak gibi yaygın bir kullanım var mıdır, mola } \\
\text { alınacak bir şey midir? Türkçe’de mola verilir bu yabancı bir } \\
\text { kullanımın çevirisi gibi.” }\end{array}$ \\
\hline Nalan nine anlat. & $\begin{array}{l}\text { T1 “nine anlat” ile ne anlatılmak istenmektedir? Bu ifade hem anlam } \\
\text { hem de dilbilgisi yönünden yanlıştır. “ }\end{array}$ \\
\hline Leman orman al. & $\begin{array}{l}\text { T2 “orman” satılacak ya da alınacak bir şey bir şey değildir. Bir } \\
\text { çocuğa bu ifade nasıl kullanılabilir.” }\end{array}$ \\
\hline İki tane nane al. & $\begin{array}{l}\text { T5 “nane tane ile mi alınıyor. Sokak ağzında kabul görebilir. Ancak } \\
\text { bizim görevimiz bunu değil olması gerekeni ölçünlü dili öğretmek. }\end{array}$ \\
\hline
\end{tabular}


Cümlelerin anlam bütünlüğü yoktur.

Örneğin öğrencilerden, “itti eti Ali” ,“at atleti Ela,” “telli Talat al atlet.” gibi karışık olarak verilen kelimelerden anlamlı cümleler oluşturulması istenmektedir. Verilen kelimelerden oluşabilecek cümleler şunlardır: "Ali eti itti” ve "Ela atleti at", "Talat telli atlet al.”. Bu cümleler yine uzmanlara göre dilbilgisi yönünden doğru gibi görünse de anlamlı görülmemiştir.

Yapılan gözlemlerde de çocuklardan ZS, ÇT ve TA' nın karışık olarak verilen kelimelerden cümle kuramadıkları görülmüştür. Örneğin ZS "bilmem anlamadım, cümle olmuyor” şeklinde cevap vermiş, cümle kurmasına yardımcı olunduğunda ise cümlelerin "çok komik" olduğunu ifade etmiştir. Bu durumunda anlamlı okuma ve uygun hızda okuma önünde engel teşkil ettiği gözlenmiştir. Çocuk hem sese hem de anlamını bilmediği kelimeye odaklandığı için okuma seslendirme boyutu ile kalmıştır. Çünkü göz, okurken kelimelere ne kadar aşina ise, bir sıçramada kavradığı alan da o kadar geniş olur. Göz, kelime klişelerine ve bunların muhtevalarına alışık olmadığı zaman, satır üzerinde ritmini bozan birtakım gerileme hareketleri yapar. Gerileme hareketleri çabuk okumayı ve okunanı çabuk anlamayı güçleştirir. Okumanın asıl amacı anlamı kavramak olduğuna göre, kelime şekillerinin, anlamlarıyla aynı zamanda kavranması gerekir. Anlam, hem kelimelerin özel şekillerini tanıma, hem de söz gelişinden yararlanılması bakımından okumanın en önemli unsurunu teşkil eder (Aytaş, 2005).

Yapılan görüşmelerde de aileler çocuklarının sordukları "Ali neden eti itiyor?" veya "Ela neden atleti atsın ki?”, "hiç telli atlet olur mu?” şeklindeki sorularına cevap bulamadıklarını, kendilerinin bile anlamsız buldukları cümleleri çocuklarına anlatmaya çalıştıklarını, fakat mantıklı bir açıklamasını yapamadıklarını ifade etmişlerdir. Bu durumun anlamlı ve hızlı okuma açısından sıkıntıya neden olduğu söylenebilir.

Anlamı bilinmeyen kelimeler anlam kargaşasına neden olmaktadır.

\section{"Ela ile Lale elti" \\ "Onat on ton ot al"}

gibi bir cümle çocuğa verildiğinde heceleyerek, duraksayarak da olsa seslendirebilmektedir. Ancak yapılan gözlemlerde FY, OÖ, ÇT, KK, TA, ÖK, YD ve DK'nın elti kelimesinin ne anlama geldiğini bilmediği gözlenmiştir. Bu bağlamda değerlendirildiğinde okumanın gerçek anlamda gerçekleştiğini söylemek güçtür.

Bond, Tinker, Wasson, \& Wasson (1989)'a göre okuma, yazılı sembollerin okuyucuya önceden bildiği bir anlamı hatırlatmasıdır. ZS VE DC dışındaki sekiz çocuk için "elti” kelimesi için yapılan iş okuma değil seslendirmedir. Benzer şekilde "Onat on ton ot al." cümlesindeki "ton” kelimesini bilmeyen çocuk cümleye farklı anlamlar yükleyebilmektedir. Örneğin yapılan gözlemlerde cümleyi okuması istenen ÇT cümleyi duraksayarak, heceleyerek de olsa okuyabilmiş, fakat ne anladığı sorulduğunda "10 renk tonunda ot mu demek istiyor, herhalde bilmem" şeklinde cevap vermiş, yine anlamını tam olarak anlayamadığı için yapılan iş seslendirmenin ötesine geçememiştir. Çünkü okuma, Lewis, \& Doorlag (1983)'a göre kelimeyi tanıma ve anlama gibi iki temel boyuttan oluşmaktadır. Dolayısıyla kelimeyi tanımayan çocuk için anlamanın oluşması beklenemez. Oysa ki okumada en önemli iş anlamadır. Okuma ile anlama arasında neden-sonuç ilişkisi vardır. Okuyucu yazarın mesajını kendi ön bilgisi ile birleştirerek anlamlandırır. Böylece okuma anlamını bulur. Anlamadan yapılan iş okuma değil yalnızca seslendirmedir (Yılmaz, 2006). Yukarıda örnek olarak verilen cümleler çocuğun anlam kurma süreci ve anlayarak okumasını engelleyebilir. Bu bulgu da çocuğun hızlı ve anlamlı okumasını engelleyecek unsurlar arasında sayılabilir.

Eş sesli kelimelerin bir arada kullanılması anlamayı zorlaştırmaktadır. 
"Ela atlet al.

"Ela atlet, Lale atlet".

Yukarıdaki iki cümlede "atlet” eş sesli iki kelimedir. Çocuğa eşsesli kelimelerin ne olduğu anlatılmadan bu iki cümle arasındaki farkı anlaması beklenemez. Türkçe programında da eş sesli kelimeler "eş sesli kelimelerin anlamlarını ayırt eder" kazanımıyla ilköğretim ikinci sınıfın konuları arasındadır ve öğrenci seviyesine uygun değildir. Ayrıca çocuk sözcüklerin eş sesli olarak kullanıldığını biliyor olsa dahi kullanılan sözcüğün farklı anlamlarını bilmiyorsa bu da anlamlı ve doğru okuma açısından yanlıştır.

“Ela atlet al.”, “Ela atlet, Lale atlet” cümleleri yapılandırmacı öğrenme yaklaşıma göre değerlendirildiğinde yaklaşımla da uyuşmadığı söylenebilir. Çünkü yapılandırmacı yaklaşıma göre öğrencinin cümleleri kendilerinin yapılandırması beklenmektedir. Çocuk “atlet” örneğinde olduğu gibi bir kelimenin birbirinden farklı anlamlarda kullanıldığını bilmiyor ise ya da anlamını bilse dahi kelimeleri daha önce kullanmamışsa bildiği kuralı uygulamada gösteremez. Bu nedenle öğrencinin kendisinin yapılandırmadığı cümlelerle gerçekleştirilen öğretim uygulamalarının yapılandırmacı öğrenme yaklaşımını yansıtmadı ̆̆ı söylenebilir.

Bazı görseller görsel okuma açısından yanlış kullanılmaktadır.

İlk okuma-yazma öğretiminde kullanılan ders kitabı ve çalışma materyallerinde görsellerin yanlış kullanımı ile ilgili örneklere de rastlanmıştır.

Örneğin;

1. "Ata eti etti.

2. "Ali tatili 7"

Örneklerdeki görseller, görsel okuma açısından yanlış kullanılmış görsellerdir ve bu nedenle anlamlı okumayı engelleyen unsurlar arasında sayılabilir. Çünkü görsel okumada kullanılan görseller her öğrenci için aynı şeyi ifade etmelidir. Verilen birinci örnek ile ilgili olarak öğrencilerin görsele baktığında o görseli nasıl okuması gerektiğini kestiremedikleri gözlenmiştir. Öğrenciler o görsel için et, mangal, şiş gibi kelimeler kullanmışlardır. Böylece "Ata eti et etti”, "Ata eti şiş etti”, “Ata eti mangal etti” gibi cümleler ortaya çımıştır. Çünkü görselin tam olarak hangi kelimeye karşılık geldiği anlaşılamamaktadır. Ayrıca oluşturulan cümlelere bakıldığında Türkçe'nin standart kullanımına uygun olmadığı da anlaşılmaktadır. Türkçe'nin standart kullanımında "eti mangal etmek", "eti şiş etmek" veya "eti et etmek" gibi bir kullanımlara rastlanmamaktadır. Günlük konuşma dilinde kullanılmayan, hatta kullanılsa bile hatalı bir kullanım olarak görülebilecek türden cümlelerle okuma yazma öğretmek, standart dil kullanımı açısından sakıncalı görülmektedir. Bu öğrencilerin velileri ile yapılan görüşmelerde velilerin hemen hepsi "çocuklarının okuma çalışmalarında bu görselleri kendilerinin bile farklı söylediklerini bu durumunda çocuklarına verecekleri desteğin kalitesini azalttı̆̆ını dolayısıyla çocuklarının okumalarını da zorlaştırdığını" ifade etmişlerdir.

Verilen ikinci örneğe bakıldığında ise görselin tamamen yanlış kullanıldığı görülmektedir. Çünkü yemek eylemi ile 7 rakamı aynı şeyi ifade etmemektedir. Bu ve benzeri kullanımlar çocukların soyut düşünceleri hatalı olarak somutlaştırmasına neden olabilir.

Ses Temelli Cümle Yöntemi’nde sesler aynı anda verilmediği için bazı kelimelerin yazımı mümkün olamamakta ve bu kelimelerin yerine görseller kullanılarak okumanın gerçekleştirilebileceği ifade edilmektedir. Ancak, görsel, soyut kavramları somut bir hale dönüştürebilmek için kullanılır. Sözel bilgilerin somutlaştırılmasını sağlayan görseller okuma ve yazma öğretiminde görsellerin kullanımı çocuğun yaş ve gelişimine uygun olarak kullanılması durumunda 
anlamlı okuma sürecini olumlu yönde etkileyebilir. Kullanılan görsellerin yerindeliği ve öğrenciye uygunluğu, somut işlemler döneminde olan çocuğun görseli anlamlandırması ve görsel okumayı gerçekleştirebilmesi açısından çok önemlidir.

Görseller kullanılarak oluşturulmaya çalışılan cümle yapıları ile ilgili görüşüne başvurulan T1;

“Ses Temelli Cümle Yöntemi’nde seslerin gruplara ayrılması ve okuma öğretiminin ilk aşamalarında sınırlı sayıda harfle öğretim yapılmasının beklenmesi böyle bir yanlış uygulama ile sonuçlanmıştır. Az sayıda harfle ne yapılabilir ki. Hele bir de amaç çocuğu bir an önce okuma yazmaya geçirmek olunca görseller de yanlış kullanılır, ifadeler de"

şeklinde son bir not eklemek istediğini belirtmiştir.

\section{5) Ailelerin Okuma Sürecine Etkilerine İlişkin Bulgular}

Aileler de okuma sürecini olumsuz yönde etkilemektedirler. Aileden kaynaklanan eksiklik ve hatalar, ailenin yöntem hakkında bilgi sahibi olmaması ve dolayısıyla yanlış yönlendirmelerinden kaynaklanmaktadır. Çocukların dil becerileri, içinde doğup büyüdükleri aile ortamı ile sosyal, ekonomik ve kültürel bir çevrede gelişir. Bugüne kadar yapılan birçok araştırma sosyal, ekonomik ve kültürel çevrenin dil becerileri üzerinde etkili olduğunu ortaya koymuştur (Çelenk, \& Çalışkan, 2004).

Yapılan görüşmelerde velilerin Ses Temelli Cümle Yöntemi’ni bilmedikleri bu nedenle de seslendirme çalışmaları yaparken ya da birleştirme ve çözümlemeler konusunda çocuklarına yeterince yardımcı olamadıkları bulgusuna ulaşılmıştır. Örneğin ZS’nin annesi kendisinin harfleri “a- be- ce- de” şeklinde okuduğunu örneğin " $n$ ” sesini de "ne” şeklinde seslendirdiği için çocuğunun "ana" kelimesini "a-ne-a" şeklinde okuduğunu ifade etmiştir. Böyle bir yönlendirme de anlamlı okuma önünde engel olarak görülmektedir.

Burada dikkati çeken ve öğrenci velilerinin de açıklamakta zorlandıklarını ifade ettikleri bir başka konuda kısaltmaların okunuşu ile ilgilidir. Örneğin DC’nin babası çocuğunun “TRT Çocuğu izle" dediğinde DC "baba yanlış okuyorsun, te re te şeklinde okunmaz" şeklinde cevap verdiğini ve nasıl okuması gerektiğini de artık karıştırdığını çocuğuna cevap veremediğini belirtmiştir.

$\mathrm{Bu}$ araştırmada ailelerin sunduğu yardımların okul öğrenmeleri ile çelişmesi nedeniyle çocuğun okuma sürecinin olumsuz etkilendiğini söylemek mümkündür.

\section{Tartışma}

Araştırma bulgularına göre okuma ve yazma öğretimi için seçilen yöntemin anlamlı okumayı etkilediği söylenebilir. Ancak bu kullanılan yöntemin dil yapısı veya öğrenci gelişim özelliklerine uygunluğu gibi özelliklerden kaynaklı olabileceği gibi yöntemin yanlış kullanımı ve/veya yetersizliği de olabilir. İlk okuma yazma öğretimindeki başarı büyük ölçüde kullanılan yöntemin etkisine bağlıdır (Kılıç, 2000). Çünkü çocuğun anlamı kavraması, okuma yazma öğretiminde kullanılan yöntemle yakından ilişkilidir (Çınar, 2004). Ancak her öğrenme alanında olduğu gibi ilk okuma ve yazma öğretiminde tek bir doğru yöntemden söz edilemez, ya da yöntem tek başına suçlu bulunamaz. Çünkü hiçbir ders için hiçbir yöntem sihirli bir değnek değildir (Küçükahmet, 2001). Yöntem öğrenci özellikleri ile uyuşmuyorsa, öğretmen tarafından etkili bir şekilde kullanılmıyorsa, hazırlanan ders materyalleri yöntemin özünü yansıtmıyorsa olumsuz sonuçlar doğurması kaçınılmaz olabilir.

Okuma yalnızca yazıyla iletilen anlamı seslere dönüştürmek (seslendirmek) değil, iletideki anlamı kavramaktır. İlk okuma yazma öğretiminin amacı sadece okur-yazar yetiştirmek değil 
"doğru, hızlı, anlamlı bir okuma, okuduğunu anlama, anladığını anlatma, anlattığına yorum katma" amacı doğrultusunda okuma yazmayı bilir nesiller yetiştirmektir (Demirel, 1995). Bu nedenle yöntem seçilirken öğrenci özellikler, yöntemin uygulayıcısı olan öğretmen, öğretimde kullanılacak araç gereç ve aileler ile birlikte alınmalıdır. Çünkü;

1. Çocuğun okula başlaması ve okuma-yazma öğrenmesi öncelikli olarak okul olgunluğu gerektirir. Çocuğun okul öğrenmelerinde başarılı olması bireysel öğrenme hazırlığına yani bilişsel, dilsel, fiziksel, duyuşsal ve sosyal gelişime bağlıdır. Eğer çocuk bu gelişim alanlarından biri veya birkaçı yönünden okula başlamak için gerekli gelişim özelliklerini kazanmamışsa başarısızlık yaşaması kaçınılmazdır (Kutluca-Canbulat, 2012). Çocuğun bireysel olarak öğrenmeye hazır olmasının yanında gelişim dönemi açısından da Piaget'e göre bu dönemdeki çocuklar "somut işlemler" dönemindedir (Küçükkaragöz, 2011). Çocuk bu dönem boyunca somut nesne ve olayların sembolik temsilleri ile işlemler yapmaya başlar. $\mathrm{Bu}$ dönemde çocuğun yürüttüğü bütün işlevler tamamıyla fiziksel bir gerçeğe bağlıdır. Somut olarak var olmayan nesne ya da durumlar üzerinde düşünce üretmek henüz olanaklı değildir. (Onur, 1987). Bu nedenle Ses Temelli Cümle Yöntemi ile öğrenmek çocuk için soyut olan seslerden başlaması açısından anlamlı okuma sürecini etkileyebilmektedir.

2. Yöntemin yapısal özellikleri anlamlı okumayı olumu/olumsuz olarak etkileyebilmektedir. Bu nedenle ilk okuma-yazma öğretim sürecinde öğrencinin ön bilgilerinden hareketle özellikle ve öncelikli olarak anlamlı heceler elde edilmelidir. Oluşturulacak hecelerin dilde kullanım sıklığına sahip olması, anlamın açık, somut ve görselleştirilebilir olması (canlandırılabilir, resmedilebilir), işlek hece yapısına sahip olmasına, kolay okunmasına, somut öğeler kullanılarak kısa sürede cümlelere ulaşılmasına dikkat edilmelidir (Beyazıt, 2007).

Türkçe'de yeni bir kelime türetileceği veya kelime tabanı cümle içinde kullanım alanına çıkacă̆ı zaman tabanın sonuna ilgili ekler getirilir. Yeni kelimede eklem yerleri şeffaf olmalı ve taban ile ek apaçık görünmelidir (Kaya, 1999). Bilir (2005)'e göre harf, ses, hece ve sözcük/kelime yöntemleri özünde ulama ve ekleme mantığıyla işlediklerinden, önce ses ve sembollerin tanınması, (ezberlenmesi) sonra bunların birbirine ulanması (çatılması) ve eklenmesi gerekmektedir. Bu süreç hem okumada, hem de yazmada hızı düşürmektedir. Hatta öyle ki bu ulama ve ekleme zihinsel bir süreç olduğundan çocukta alışkanlık yapmakta ve sessiz okuma sırasında da devam etmektedir. Bu da bireyin sessiz okumada da hızlı okuyamamasına neden olmaktadır. Bu yöntemle okuma-yazma öğrenen öğrencilerin ileride "hızlı okuma teknikleri” konusunda eğitilmeleri zorunlu hale gelmektedir (Bilir, 2005).

3. Eğitim programının etkililiği öğretim programlarının uygulayıcısı olan öğretmenlerin etkililiği ile doğru orantılıdır (Erginer, 1996; Sönmez, 2003). İlk okuma yazma öğretiminde en etkili faktörlerden birisi sınıf öğretmenidir. Öğretmen, öğrenciyle sürekli etkileşimde bulunan, eğitim programını uygulayan, öğretimi yöneten, hem öğrencinin hem de öğretimin değerlendirmesini yapan kişidir (Beyazıt, 2007). İlk okuma yazma öğretiminde uygulanacak olan yöntemin başarısı, yöntemi uygulayacak kişilerin yöntem hakkında yeterli bilgiye sahip olup olmadıklarına göre değişebilir (Yılmaz, \& Ağırtaş, 2009). Bu nedenle yöntemin uygulayıcıları olan öğretmenlere çok büyük görevler düşmektedir. Öğretimin gerçekleşmesinde öğretmenin niteliği ile birlikte kullanılan yöntemin de eğitimin kalitesini önemli derecede belirleyici özelliği vardır. Düzgün okuma, doğru ve işlevsel bir yazı yazma becerisinin kazandırılabilmesi ancak planlı ve programlı bir çalışmanın ürünü olabilir (Güleryüz, 1991). Öğretmenin etkili bir öğretim yapabilmesi için öğrencilerinin gelişim özellikleri ve bireysel farklılıklarıyla tanıması gerekir. Ayrıca öğretmen öğrencinin gelişim özelliklerini bilmekle birlikte öğrencilerine uygun öğretim yöntem ve tekniklerini nasıl ve hangi araçlarla sunacağını da bilmelidir. 
4. Öğrenme öğretme sürecinin gerçekleşmesinde en önemli katkıyı sağlayan öğretmen ve öğrenci arasında bilgi taşıyan öğe olması bakımından öğretim materyalidir. Bu nedenle ilk okuma-yazma öğretiminde kullanılan materyallerin de okuma yazma öğretimi açısından önemi büyüktür. Ancak öğretim materyalinin etkili bir şekilde işe koşulması için bir takım özelliklere sahip olması gereklidir. Bu özelliklerden bazıları şu şekilde sıralanabilir: Öğretim materyali, basit, sade ve anlaşılabilir olmalı, dersin ve konunun amaçlarına uygun seçilmeli ve hazırlanmalı, kullanılan yazılı metinler, görsel-işitsel öğeler, öğrencinin pedagojik özelliklerine uygun olmalı ve öğrencinin gerçek hayatıyla tutarlılık göstermeli, mümkün olduğunca gerçek hayatı yansıtmalı, materyaller sadece öğretmenin rahatlıkla kullanabildiği türden değil, öğrencilerin de kullanabileceği düzeyde basit olmalıdır (Çelik, 2012).

Öğretim materyallerinin etkin bir şekilde hazırlanmasında ve seçilmesinde, belirtilen ilkelerin kontrol edilebilmesi için, her öğretmenin öncelikle aşağıda verilen şu soruları cevaplandırılması gerekir.

- Materyal, eğitim programıyla uyumlu ve programı destekleyici nitelikte midir?

- Materyalin içerdiği bilgiler doğru ve güncel midir?

- Materyalde kullanılan anlatım türü açık ve anlaşılabilir mi?

- Materyal, öğrenciyi güdüleyici ve ilgisini çekici nitelikte midir?

- Materyal, öğrencinin derse katılımını sağlayabilir nitelikte midir?

- Materyal teknik özellikleri açısından yeterli midir?

- Materyalin etkinliği hakkında önceden elde edilmiş bilgiler var mı?

- Materyal, içerik açısından tarafsız ve öğretimsel nitelikte midir?

- Materyalin kullanımı için gerekli kullanım kılavuzları (öğretmen-öğrenci) ve yazılı dokümanlar var mı? (Heinich, Molenda, \& Rissel,1993; akt. Seferoğlu, 2013).

Öğretmenler hangi yöntem olursa olsun öğrenciye sunacağı metinleri, anlam, Türkçe’nin yapısına uygunluk vb. açılarından değerlendirerek öğrencilerine sunmalıdır.

Öğretim eğer teknoloji destekli yapılandırılacaksa kullanılan öğretim teknolojisi öğretme sürecinde öğretmenin yerine geçecek bir seçenek olarak değil, sistemi tamamlayıcı, güçlendirici bir araç olarak girmesi esastır. Bilgisayar destekli öğretim süreci, öğrencinin güdülenmişlik düzeyi, yenilik, etkileşim düzeyi, bireysel öğrenme farklılıkları, öğretmenin rolü, ders yazılımının türü kapsamı ve niteliği gibi değişkenin etkisindedir. Ders yazılımlarının niteliği ve okul programları ile bütünleştirilmesi en önemli değişkenler olarak ifade edilmektedir. Bu nedenle de bu tür yazılımların hazırlanması, geliştirilmesi ve değerlendirilmesi çok dikkatli ve titiz bir çalışmayı gerektirmektedir (Seferoğlu, 2013). Öğretmen bu tür yazılımları kullanırken çok dikkatli olmalı, öğretmenlik rolünü kendisi üstlenmelidir.

5. Okullarda verilen eğitimin daha nitelikli olması için ailenin de evde bu konulara destek vermesi gerekmektedir. Okullarda öğrencilere kazandırılmaya çalışılan kazanım ve becerilerin daimi olması için sürekli tekrar edilmesi gerekmektedir. Tekrar edilmeyen bilgi ve becerilerin unutulacağı muhakkaktır (Şerefli, 2008 ). Çocuğun aile de elde ettiği bilgi ve beceriler onun okuldaki başarısını etkiler. Çocuğun aile içinde öğrendiği bilgi, tutum ve beceriler okulda öğrendiklerini destekler nitelikte ise çocuk okulda daha başarılı olur (Doğanay, 2006; akt. Şerefli, 2008). Ancak ailenin çocuğu desteklemesi eğitim- öğretim programlarından haberdar olması ile yakından ilişkilidir. Aile kendisinin bilgi sahibi olmadığı bir konuda çocuğunu destekleyemez ya da desteklemek isterken yanlış yönlendirebilir. 


\section{Sonuç}

Araştırma sonucunda anlamlı okumanın, gerek yöntemin yapısından gerek öğretmen ve uygulama yanlışlarından, gerekse de aile tarafından olumsuz olarak etkilendiği görülebilmektedir.

1. Öğrenci özellikleri ve bireysel farklılıkları okul öğrenmelerine uygunluk açısından değerlendirildiğinde okuma yazma öğretim sürecini etkilemektedir.

2. Yöntemin yapısı Türkçe’nin işlek ve ölçünlü dil yapısını doğru yansıtamamaktadır. Bu da öğrencinin duraksayarak ve yanlış heceleyerek okumasına neden olmakta ve okuma kalitesini etkilemektedir. Bu nedenle yöntem bu yönüyle tekrar ele alınmalı ve kelimeler oluşturulurken Türkçe’nin bu özelliğine uygun hale getirilmelidir.

3. Yöntemin uygulayıcısı olarak öğretmen Ses Temelli Cümle Yöntemi ile öğretim yapabilecek eğitimi almamıştır. Bu nedenle uygulama açısından yetersizdir.

4. Ders materyallerinin seçiminde öğrenci seviyesine uygunluk, Türkçe'nin ses ve anlam yapısına uygunluk, Türkçe’nin doğru kullanımı gibi kriterler dikkate alınmamıştır. Öğretmenlerin okuma yazma öğretiminde kullanılacak metinler konusunda seçici olmamaları anlamlı okumayı olumsuz yönde etkilemektedir. Ses Temelli Cümle Yöntemi ile ilgili olarak hazırlanmış materyallerde anlamlı okumayı engelleyecek örneklere rastlanmıştır. Bu da yöntemin kendisinden kaynaklanmaktadır. Çünkü tüm sesler bir arada verilmediği için verilen seslerle ilgili cümleler kurulmak istendiğinde anlamsız, ya da anlaşılması zor ifadeler ortaya çıkmaktadır. Öğretmenlerin de metin seçimi bakımından çok seçici olmadıkları göz önünde bulundurulduğunda bu durumun öğrencinin yaşamı boyunca kullanacağı anlamlı okuma süreci bakımından sıkıntıya sebep olacağı düşünülmektedir.

5. Araştırmada verilen örnek cümlelerle yapılan öğretimin okumadan çok seslendirmeye yönelik olduğu söylenebilir.

- Okuma yazma öğretiminde kullanılan bazı metinler yapılandırmacı yaklaşım ile çelişmektedir.

- Görsel okuma için kullanılan görseller yanlış kullanılmakta ve her öğrenci için aynı şeyi ifade etmediği için amacına ulaşamamaktadır. Bu durum da anlamalı ve hızı okumayı engelleyebilmektedir.

6. Aileler Ses Temelli Cümle Yöntemi’ni bilmedikleri ve çocuklarının okumalarını kendi alışkanlıklarına bağlı olarak destekledikleri için çocuklarının okumalarını olumsuz yönde etkilemektedirler.

\section{Öneriler}

Araştırma sonucunda elde edilen bulgulara dayanarak Sever (2005)'in de ifade ettiği gibi ilköğretimin birinci sınıfından başlayarak okuma kültürü edinmiş kişiler yetiştirebilme genel bir amaç olarak benimsenmelidir. Bu nedenle dilin anlatım gücü ve güzelliğini yansıtan, duyma ve düşünme sorumluluğu veren, kurallarının yaşama geçirildiği çeşitli türdeki metinlerle karşılaştırılması yeğlenmelidir. Metinlerin dilsel düzenlenişi, söz varlığını yansıtma yeterliği, çocuklara anlam evrenlerine uygun duyma ve düşünme sorumluluğu vermesi, onları anlamın oluşmasına ortak edebilme, düş ve düşünce üretmeye yöneltme başarısı, çocukları okul türü öğrenmenin ilk yıllarından başlayarak yazılı kültüre yönelten temel etkenlerdir. Türkçe öğretimi, çocukları sanatçı duyarlılığıyla buluşturan, onlara bilgiden çok anadilinin yaratıcı olanaklarıyla yaşam ve insan gerçekliğini sezdiren, tanıtan, gizli güçlerinin farkındalığını sağlayan bir sorumluluk üstlenmelidir.

Türkçe’nin öğretiminin temellerinin atıldığı Ses Temelli Cümle Yöntemi ile okuma yazma öğretimi yukarıda sözü edilen özelliklere hizmet edebilmelidir. 
Bu bağlamda Ses Temelli Cümle Yöntemi ile okuma yazma öğretim sürecine aşağıdaki öneriler getirilebilir.

- İlk okuma öğretiminde kullanılan ders kitabı, okuma setleri ve çalışma materyallerinde öğrencinin anlamlandırarak okumasına yönelik metinlere yer verilmelidir. Çünkü okuma yalnızca seslendirme işi değildir. Bu nedenle okuma yazma materyalleri Türkçe'nin yapısına ve anlamlandırma sürecine uygun bir şekilde yeniden oluşturulmalıdır. Yanlış kullanımlar kitap ve çalışma materyallerinden bir an önce çıkarılmalı ve hazırlanacak olan kitap, çalışma kitabı ve çalışma yapraklarında kullanılacak olan cümleler özenle seçilmelidir.

- Öğretmenler okuma yazma materyallerini seçerken daha seçici olmalıdır.

- Öğrencide dünya görüşü ve bakış açısı geliştirildiği bir dönemde kullanılan ifadelere özellikle dikkat edilmelidir. "Ali itaat et” cümlesi örneğinde olduğu gibi ifadeler çocuğun duygu ve düşüncelerini ifade edebilme becerisinin geliştirilmeye başlandığı bu sınıf seviyesinde "itaat" gibi bir kelimenin öğretilmesi zaten anlamını bilmediği bir cümle ile karşılaşmasının yarattığı karmaşanın yanında anlamını sorduğunda aldığı cevap bu karmaşayı daha da arttıracaktır.

- Aileler Ses Temelli Cümle Yöntemi ve uygulamaları konusunda bilgilendirilmelidir.

- Ses Temelli Cümle Yöntemi Türkçe’nin yapısına uygun olarak uygulanmalıdır.

\section{KAYNAKLAR}

Akyol, H., \& Temur, T. (2008). "Ses Temelli Cümle Yöntemi ve Cümle Yöntemi ile Okuma Yazma Öğrenen Öğrencilerin Okuma Becerilerinin Öğretmen Görüşlerine Göre Değerlendirilmesi”. Mustafa Kemal Üniversitesi Sosyal Bilimler Enstitüsü Dergisi, Cilt: 5/9, 78-95.

Aldemir, M. (2005). İlk Okuma ve Yazma Öğretiminde Kullanılan Çözümleme ve Ses Temelli Cümle Yönteminin Karşılaşstırılması. Yayımlanmamış Yüksek Lisans Dönem Projesi. Yüzüncü Yıl Üniversitesi Sosyal Bilimler Enstitüsü, Van.

Arslantaş, H. İ., \& Cinoğlu, M. (2010). “illk Okuma Yazma Öğretiminde Ses Temelli Cümle Yöntemiyle Çözümleme Yönteminin Karşılaştırılması”. İnönü Üniversitesi Eğitim Fakültesi Dergisi, Cilt. 11/1, 81-92.

Aytaş, G. (2005). “Okuma Eğitimi”. Türk Eğitim Bilimleri Dergisi. http://www.tebd.gazi.edu.tr/arsiv/ 2005_cilt3/sayi_4/461-470.pdf adresinden alınmıştır.

Balun, H. (2008). İlköğretim 1. Kademede Uygulanan Görsel Okuma ve Görsel Sunu Öğrenme Alanının Türkçe Öğretiminde Kazanımlara Ulaşmadaki Etkililiği (Bingöl-Elazığ-Diyarbakır Örneği). Yayımlanmamış Yüksek Lisans Tezi. Fırat Üniversitesi Sosyal Bilimler Enstitüsü Eğitim Bilimleri Anabilim Dalı, Elazığ.

Beyazıt, N. (2007). İlk Okuma Yazma Öğretiminin Kazandırılmasında Çözümleme Yöntemi ve Ses Temelli Cümle Yönteminin Farklı Bakış Açılarıyla Değerlendirilmesi. Yayımlanmamış Yüksek Lisans Tezi. Mustafa Kemal Üniversitesi Sosyal Bilimler Enstitüsü İlköğretim Anabilim Dalı, Hatay.

Bilen, M. (1999). Plandan Uygulamaya Öğretim. Ankara: Anı Yayıncllık.

Bilir, A. (2005). İlköğretim Birinci Sınıf Öğrencilerinin Özellikleri ve İlk Okuma Yazma Öğretimi. Ankara Üniversitesi Eğitim Bilimleri Fakültesi Dergisi. 38, 87-100.

Binbaşıŏglu, C. (2005). “İlk Okuma ve Yazma Programı ve Öğretimi”. Eğitimde yansımalar VIII: Yeni İlköğretim Programlarını Değerlendirme Sempozyumu. Kayseri: Erciyes Üniversitesi: Tekışı Eğitim Araştırma Geliştirme Vakfı, 22-135.

Bond, G., Tinker, M. A, Wasson, B. B., \& Wasson, J. B. (1989). Reading Difficulties, Their Diagnosis and Correction. ( $6^{\text {th }}$ edition). New Jersey: Prentice Hall, Englewood Cliffs.

Çelenk, S. (1992). "Farklı Yöntemler Açısından İlk Okuma Yazma Öğretimi ve Bir Yöntem Denemesi”. Hacettepe Üniversitesi Eğitim Fakültesi Dergisi, Sayı 8, 369-378.

Çelenk, S. (2002). “illkokuma-Yazma Öğretiminde Karşılaşılan Sorunlara İlişkin Öğretmen Görüşleri”. İlkögrretim-Online 1 (2), 40-4 http://www.ilkogretim-online.org.tr. 
Çelenk, S. (2007). İlk Okuma Yazma Programı ve Öğretimi. Ankara: Maya Akademi.

Çelenk, S., \& Çalışkan, M. (2004). "Bazı Sosyo-Ekonomik Faktörlerin Okuduğunu Anlama Başarısına Etkisinin İncelenmesi”. Çağdaş Ĕgitim Dergisi, 309, 24-33.

Çelik, L. V. (2012). “Öğretim Materyalinin Hazırlanması ve Seçimi”. Ed. Özcan Demirel, \& Eralp Altun. Öğretim Teknolojileri ve Materyal Tasarımı, 27-66. Ankara: Pegem Akademi.

Çınar, İ. (2004). "Birleştirilmiş Sınıflı İlköğretim Okullarında İlk Okuma Yazma Öğretimine İlişkin Bir Araştırma”. İnönü Üniversitesi Eğitim Fakültesi Dergisi, 5 (7).

Çiftçi, F. Yüksel İ., Mühürcüoğlu A. İ., \& Yılmaz M. (2005). "Ses temelli cümle yöntemine göre ilk okuma-yazma öğretmen elkitabı”. http://okulweb.meb.gov.tr/14/01/527888/sestemellicmleyntemi.htm

adresinden 19.10.11 tarihinde alıntılanmıştır.

Demirel, Ö. (1995). Türkçe Programı ve Öğretimi. Ankara: Usem Yayınları.

Demirel, M. (2006). İlk Okuma Yazma Öğretimindeki Değisşikler Üzerine Bir Araştırma. Yayınlanmamış Yüksek Lisans Tezi. Selçuk Üniversitesi Sosyal Bilimler Enstitüsü, Konya.

Erginer, E. (1996). İlk Okuma ve Yazma Öğretimindeki Öğretmen Davranışlarının Değerlendirilmesi ve Sınıf Öğretmenliği Eğitimine Yansımaları. Yayınlanmamış Yüksek Lisans Tezi. Ankara Üniversitesi, Sosyal Bilimler Enstitüsü Eğitim Programları ve Öğretimi Anabilim Dalı, Ankara.

Ferah, A. (1999). "illk Okuma-Yazma Döneminde Görsel Algı ve Zekâ İle Okuma-Yazma Arasındaki İlişkilerin Araştırılması”. IV. Ulusal Eğitim Bilimleri Kongresi, 327-341.

Güleryüz, H. (1991). Programlanmış İlk Okuma ve Yazma Öğretimi Öğretmen El Kitabı. Ankara: Semih Yayınları.

Gündüz, Y. (2006). “Çözümleme (Cümle) Yöntemi İle Ses Temelli Cümle Yönteminin Karşılaştırılması”. Çağdaş Ĕ̈itim Dergisi, 333-340.

Güneş, F. (2005). Niçin Ses Temelli Cümle Yöntemi? Eğitimde Yansımalar VIII: Yeni İlköğretim Programlarını Değerlendirme Sempozyumu. 14-16 Kasım 2005 Erciyes Üniversitesi. Kayseri.

Güzel Özmen, R., \& Doğan, Y. (2011). “İlk Okuma Yazmayı Farklı Yöntemlerle Öğrenen Öğrencilerin Okuduğunu Anlama, Okuma Hızı ve Okuma Hataları Bakımından Karşılaştırılması. Türkçe’nin Eğitimi- Öğretiminde Kuramsal ve Uygulamalı Araştırmalar”. Eds. Uzun, G., L., \& Bozkurt, Ü. Verlag die blaue eule, Essen, 2011.

Karasar, N. (2007). Bilimsel Araştırma Yöntemi. Ankara: Nobel Yayın Dağıtım.

Kavcar, C., F. Oğuzkan, \& S. Sever. (1997). Türkçe ve Sınıf Öğretmenleri İçin Türkçe Öğretimi. Ankara: Engin Yayınevi.

Kaya, C. (1999). “Türk Sözlük Sistemi Üzerine İki Not”. Doğu Akdeniz Üniversitesi Uluslararası Sözlükbilim Sempozyumu Bildirileri, 20-23 Mayıs Gazimağusa. Yayına Hazırlayan: Nurettin DemirEmine Yılmaz. Gazimağusa 2001, 83-89.

Kaya, Z. (2012). “Eğitimin Psikolojik Temelleri”. Eds. Özcan, Demirel, \& Zeki, Kaya. Eğitim Bilimine Giriş İçinde, 95-128. Ankara: Pegem A Yayıncllık.

Kılıç, A. (2000). İlk Okuma Yazma Öğretiminde Programlandırılmış Öğretime Göre Metin Yönteminin Etkililiği. Yayınlanmamış Yüksek Lisans Tezi. Hacettepe Üniversitesi Sosyal Bilimler Enstitüsü, Ankara.

Korkmaz, İ. (2007). "Yeni İlköğretim Birinci Sınıf Programının Öğretmenler Tarafından Değerlendirilmesi”. http://www.sosyalbil.selcuk.edu.tr adresinden 18.9.11 tarihinde alınmıştır.

Küçükahmet, L. (2001). Öğretimde Planlama ve Değerlendirme. Ankara: Nobel Yayın Dağıtım.

Küçükkaragöz, H. (2011). "Bilişsel Gelişim ve Dil Gelişimi”. Ed. B.Yeşilyaprak. Gelişim ve Öğrenme Psikolojisi, 84-124. Ankara: Pegem A Yayıncllı.

Lewis. R. B., \& Doorlag, D. H. (1983). Teaching Special Studies in Mainstream. Ohio: Charles E. Merill Publishing Company.

MEB (2005). İlköğretim Türkçe Öğretim Programı ve Kılavuzu (1-5. Sınıflar). Ankara: Devlet Kitapları Müdürlüğü Basım Evi.

Neyzi, O., Günöz, H., Furman, A., Bunda, Gökçay, R. G., Darendeliler, F., \& Baş, F. (2008). "Türk Çocuklarında Vücut Ağırlığı, Boy Uzunluğu, Baş Çevresi ve Vücut Kitle İndeksi Referans Değer- 
leri”. Çocuk Sağlığı ve Hastalıkları Dergisi, 51, 1-14.

Onur, B. (1987). Ergenlik Psikolojisi. Ankara: Hacettepe Taş Kitapçıllk.

Öz, F. (1998). Uygulamalı İlk Okuma Yazma Öğretimi. Ankara: Anı Yayıncılık.

Özden, Y. (1999). Eğitimde Dönüşüm-Eğitimde Yeni Değerler. Ankara: Pegem A Yayıncılık.

Seferoğlu, S. (2013). Öğretim Teknolojileri ve Materyal Tasarımı. Pegem Akademi. Ankara.

Sever, S. (2005). “2004 Öğretim Programında Türkçe Öğretimi Anlayışı.” Eğitimde Yansımalar VIII: Yeni İlköğretim Programlarını Değerlendirme Sempozyumu. Erciyes Üniversitesi. Kayseri.

Sever, S. (2011). “Okuma Kültürü Edindirme Sürecinde Temel Sorunlar ve Çözüm Önerileri”. Türkçe’nin Eğitimi-Öğretiminde Kuramsal ve Uygulamalı Araştırmalar. Eds. Uzun, G, L., \& Bozkurt, Ü. Essen: Verlag Die Blaue Eule.

Sönmez, V. (2003). Program Geliştirmede Öğretmen El Kitabı. Ankara: Anı Yayıncılık.

Şahin, İ. Turan, H., \& Apak, Ö. (2006). "İlk Okuma Öğretiminde Ses Temelli Cümle Yöntemiyle Çözümleme Yönteminin Karşılaştırılması”. Milli Eğitim Dergisi, 17, 109-129.

Şerefli, Y. (2008). İlk Okuma ve Yazma Öğretiminde Ailenin Rolü Üzerine Bir Araştırma. Selçuk Üniversitesi Sosyal Bilimler Enstitüsü İlköğretim Öğretmenliği Anabilimdalı Sınıf Öğretmenliği Bilimdalı. Yayımlanmamış Yüksek Lisans Tezi, Konya.

Tok, S., Tok, T. N., \& Mazı, A. (2008). “ilk Okuma Yazma Öğretiminde Çözümleme ve Ses Temelli Cümle Yöntemlerinin Değerlendirilmesi”. Kuram ve Uygulamada Eğitim Yönetimi Dergisi, 53- 123-144.

Turan, M., \& Akpınar, B. (2008). "İlköğretim Türkçe Dersi İlk Okuma-Yazma Öğretiminde Kullanılan Ses Temelli Cümle ve Bitişik-Eğik Yazı Yöntemlerinin Değerlendirilmesi”. Fırat Üniversitesi Sosyal Bilimler Dergisi, 18/1, 121-138. Elazı̆̆.

Yıldııım, A., \& Şimşek, H. (2008). Sosyal Bilimlerde Nitel Araştırma Yöntemleri. Ankara: Seçkin Yayıncılık.

Yılmaz, M., \& Ağırtaş, M. N. (2009). “illk Okuma Yazma Öğretiminde Ses Temelli Cümle Yönteminin Öğretmen Görüşlerine Göre Değerlendirilmesi”. Hatay İl Örneği. Mustafa Kemal Üniversitesi Sosyal Bilimler Enstitüsü Dergisi, 6, (12), 164-175.

Yılmaz, T. (2006). Yenilenen 5.sınıf Matematik Programı Hakkında Öğretmen Görüşleri (Sakarya İli Örneği). Yayımlanmamış Yüksek Lisans Tezi. Sakarya Üniversitesi Sosyal Bilimler Enstitüsü, Sakarya. 